\title{
PERBANDINGAN METODE LATIHAN PIRAMID NORMAL DAN TERBALIK TERHADAP PENINGKATAN HIPERTROFI OTOT LENGAN DAN PAHA
}

\author{
Sandra Arhesa ${ }^{1}$ dan Rudi ${ }^{2}$ \\ Universitas Majalengka, Indonesia \\ arhesasandra@unma.ac.id \& rudi@unma.ac.id
}

\begin{abstract}
ABSTRAK. Penelitian ini bertujuan untuk mengetahui perbandingan antara metode latihan piramid normal dan terbalik terhadap peningkatan hipertrofi otot lengan dan paha. Penelitian ini menggunakan metode penelitian eksperimen, desain penelitian yang digunakan pretest-posttest design, dengan populasi member Fitness Center Balai Pertemuan Bumi Sangkuriang berjumlah 50 orang. Teknik pengambilan sampel menggunakan teknik purvosive sampling. Jadi sampel yang diambil 20 orang, 10 orang menggunakan metode latihan piramid normal dan 10 orang menggunakan metode latihan piramid terbalik. Instrumen yaitu meteran, standing dumbell curls dan leg extension. Teknik Analisis Data dengan menguji rata-rata dan simpangan baku, normalitas, homogenitas dan hipotesis. Hasil analisis pada penelitian ini menunjukkan adanya pengaruh terhadap peningkatan hipertrofi otot yang menggunakan metode latihan piramid normal dan piramid terbalik serta terdapat perbandingan yang signifikan antara metode latihan piramid normal dan terbalik terhadap peningkatan hipertrofi otot terutama otot lengan dan paha, dengan peningkatan hipertrofi otot yang lebih baik menggunakan metode latihan piramid normal. Diharapkan kedepannya dilakukan penelitian untuk peningkatan hipertrofi dengan metode latihan piramid normal dan terbalik terhadap jenis otot yang lain serta penelitiannya lebih dari satu bulan dengan sampel yang lebih banyak.
\end{abstract}

Kata Kunci: Hipertrofi Otot; Latihan Beban; Metode Latihan; Sistem Piramid Normal; Piramid Terbalik.

\section{Pendahuluan}

Binaraga adalah kegiatan pembentukan tubuh yang melibatkan hipertrofi otot. Dengan melakukan latihan beban dan diet protein tinggi secara rutin, seseorang dapat meningkatkan massa otot. Seseorang yang menekuni aktivitas ini disebut binaragawan (pria) atau binaragawati (wanita). Selain menjadi gaya hidup untuk membentuk tubuh sekaligus menjaga kesehatan, binaraga juga dapat diperlombakan dalam berbagai kontes atau sebagai salah satu cabang olahraga yang kerap diperlombakan di pesta olahraga seperti Pekan Olahraga Nasional (PON) atau Sea Games.

Dalam kejuaraan binaraga, para binaragawan memamerkan otot tubuh mereka di hadapan dewan juri yang menilai penampilan fisik mereka. Dewan juri ini akan memberikan nilai berdasarkan kriteria tertentu, seperti: massa otot, simetri tubuh, bagian otot, serta penampilan yang mencakup koreografi, musik, dan tema. Otot tubuh ditonjolkan melalui serangkaian proses yang disebut cutting phase, serangkaian kombinasi dari pengurangan kadar lemaktubuh, penggelapan warna kulit (dilakukan dengan berjemur di bawah sinar 
matahari), pembaluran minyak pada tubuh, ditambah efek penyinaran panggung yang akan membantu dewan juri untuk melihat bagian otot secara lebih jelas.

Federasi binaraga dunia adalah International Federation of Body Building \& Fitness (IFBB), sedangkan Federasi binaraga nasional Indonesia adalah Persatuan Angkat Besi, Angkat Berat, dan Binaraga Seluruh Indonesia (PABBSI). Binaragawan umumnya menempuh tiga strategi untuk memaksimalkan hypertrophy otot yaitu dengan latihan beban, nutrisi, dan istirahat yang cukup.

Latihan beban merupakan salah satu macam latihan tahanan secara isotonis, yang paling sering digunakan dalam olahraga. Latihan beban adalah latihan-latihan yang sistematis dimana beban hanya dipakai sebagai alat untuk menambah kekuatan otot guna mencapai berbagai tujuan tertentu, misalnya memperbaiki kondisi fisik sedangkan tujuan latihan tahanan secara umum menurut ACSM (The American College of Sport and Medicine) meliputi kekuatan otot, daya tahan otot, hypertrophy otot, dan power otot.

Latihan beban bertujuan membangun jaringan otot dengan memicu dua jenis hipertrofi; hipertrofi sarkoplasmik dan hipertrofi miofibrilar. Hipertrofi sarkoplasmik menciptakan otot yang lebih besar sehingga menjadi tujuan latihan binaraga daripada hipertrofi miofibrilar yang lebih bersifat kekuatan dan kelenturan. Sarkoplasmik dipicu dengan meningkatkan repetisi (pengulangan), sementara miofibrilardipicu dengan mengangkat beban yang lebih berat. Keduanya secara bersama dapat meningkatkan ukuran dan kekuatan otot (dibandingkan dengan orang yang tidak latihan beban sama sekali), namun norma yang berbeda.

Banyak pelatih memilih untuk secara silih berganti menggunakan dua metode ini. Hal ini dimaksudkan agar tubuh beradaptasi (dengan mempertahankan beban lebih yang progresif), mungkin dengan menekankan metode sesuai kebutuhan mereka, misalnya seorang binaragawan yang terbiasa latihan dengan metode hipertrofi sarkoplasmikyaitu meningkatkan repetisi (pengulangan) dapat suatu waktu beralih ke hipertrofi miofibliar yaitu mengangkat beban yang lebih berat agar dapat melampaui batas plateau yakni suatu titik dimana latihannya sudah membentur batas.

Sebelum perang dunia II boleh dikatakan hampir semua pelatih olahraga menentang dimasukkannya latihan beban dalam program latihan atlet. Mereka beranggapan bahwa latihan beban membahayakan dan akan menyebabkan atlet menjadi apa yang disebut sebagai muscle bound, suatu kondisi dimana atlet akan menjadi kaku dan lamban. Otot yang berada dalam kondisi muscle bound adalah otot yang meskipun besar dan kuat, tetapi kaku dan lamban.

Kini pendapat demikian sudah banyak ditinggalkan sehingga semua pelatih yang baik memasukkan latihan beban kedalam program latihan atlet. Sementara latihan tahanan otot 
menurut ACSM adalah salah satu metode untuk meningkatkan kebugaran otot. Dalam latihan beban ada beberapa macam metode latihan kekuatan yang dijelaskan oleh Harsono (1988), diantaranya set sistem, sistem super set, split routines, burn out, metode multi-poundage dan sistem piramid.

Dalam penelitian ini peneliti bermaksud mengadopsi sistem latihan piramid yang biasanya selalu digunakan dalam latihan kekuatan atau weight training. "Pelaksanaan sistem piramid dimulai dari beban yang ringan, kemudian pada set berikutnya makin lama makin berat beban latihannya." (Harsono, 1988).

Dalam beberapa metode latihan peneliti tertarik untuk mengkaji metode latihan lainnya yang berbeda yaitu latihan dengan sistem piramid terbalik yang merupakan kebalikan dari sistem piramid normal. Keduanya bertujuan untuk membangun jaringan otot dengan memicu dua jenis hipertrofi sarkoplasmik dan hipertrofi miofibrilar. Sistem piramid normal termasuk kedalam jenis hipertrofi miofibrilar yang dipicu dengan mengangkat beban yang lebih berat sedangkan Sistem piramid terbalik termasuk ke jenis hipertrofi sarkoplasmik yang dipicu dengan meningkatkan repetisi.Oleh karena itu peneliti ingin mengkaji lebih dalam untuk melihat perbandingan efektivitas metode latihan piramid normal dan piramid terbalik terhadap peningkatan hipertrofiotot.

\section{Metode Penelitian}

Metode yang digunakan dalam penelitian ini adalah Metode Penelitian Eksperimen. Desain penelitian yang digunakan pre-experimental designyang jenis nya pretest-posttest design. Populasi penelitian ini adalah member putra Fitness Center Balai Pertemuan Bumi Sangkuriang 50 orang, member yang pasif 30 orang dan member aktif 20 orang sedangkan sample yang peneliti gunakan adalah member aktif sejumlah 20 orang, 10 orang sebagai sample pada kelompok sistem piramid normal dan 10 orang pada kelompok sistem piramid terbalik. Dalam Teknik pengambilan sampel menggunakan teknik purvosive sampling.Dalam penelitian ini penulis menggunakan instrumen seperti meteran, untuk melihat perubahan lingkar otot sebelum dan sesudah penelitian, yang dilakukan pada otot lengan dengan menggunakan latihan standing dumbell curls dan otot paha menggunakan latihan leg extension, agar bisa membedakan peningkatan hipertrofi otot dengan menggunakan sistem piramid normal dan sistem piramid terbalik.Penelitian dilaksanakan selama satu bulan dengan frekuensi tiga kali latihan dalam satu minggu atau sama dengan 12 kali latihan dengan intensitas 30-60\% dan 60-30\%. Penelitian dilaksanakan dari bulan Juli sampai dengan bulan Agustus, pada hari Senin, Rabu dan Jum'at. 
Teknik Analisis Data dengan menguji rata-rata dan simpangan baku, normalitas, homogenitas dan perbedaan dengan menggunakan SPSS 17.

\section{Hasil Penelitian}

Hasil pengolahan data dalam penelitian ini, meliputi uji rata-rata, uji simpangan baku, uji normalitas, uji homogenitas, dan uji hipotesis untuk mengetahui perbandingan metode latihan piramid normal dan piramid terbalik terhadap peningkatan hipertrofi otot. Semua pengujian tersebut merupakan persyaratan utama dalam menarik simpulan.

Tabel 1

Uji Rata-rata dan simpangan baku pada otot lengan dan paha

\begin{tabular}{|c|c|c|c|c|c|c|c|c|c|c|c|c|c|c|c|c|}
\hline & \multicolumn{16}{|c|}{ Sistem Latihan Piramid Nomal } \\
\hline & \multicolumn{4}{|c|}{ Tes Awal $(\mathrm{cm})$} & \multicolumn{4}{|c|}{ Tes Akhir (cm) } & \multicolumn{4}{|c|}{ Selisih (cm) } & \multicolumn{4}{|c|}{ Persen (\%) } \\
\hline & \multicolumn{2}{|c|}{$\mathrm{L} \mathrm{Ka}$} & \multicolumn{2}{|c|}{$\mathrm{L} \mathrm{Ki}$} & \multicolumn{2}{|c|}{$\mathrm{L} \mathrm{Ka}$} & \multicolumn{2}{|c|}{$\mathrm{L} \mathrm{Ki}$} & \multicolumn{2}{|c|}{ L Ka } & \multicolumn{2}{|c|}{$\mathrm{L} \mathrm{Ki}$} & \multicolumn{2}{|c|}{$\mathrm{L} \mathrm{Ka}$} & \multicolumn{2}{|c|}{ L Ki } \\
\hline & $\mathrm{R}$ & $\mathrm{K}$ & $\mathrm{R}$ & $\mathrm{K}$ & R. & $\mathrm{K}$ & $\mathrm{R}$ & $\mathrm{K}$ & $\mathrm{R}$ & $\mathrm{K}$ & $\mathrm{R}$ & $\mathrm{K}$ & $\mathrm{R}$ & $\mathrm{K}$ & $\mathrm{R}$ & $\mathrm{K}$ \\
\hline $\mathrm{x}$ & 30,5 & 32 & 30,1 & 31,5 & 31,3 & 32,8 & 30,9 & 32,3 & 0,8 & 0,8 & 0,8 & 0,8 & 2,6 & 2,5 & 2,6 & 2,5 \\
\hline $\mathrm{S}$ & 3,4 & 3,2 & 3,5 & 3,5 & 3,4 & 3,2 & 3,5 & 3,5 & 0,2 & 0,2 & 0,2 & 0,2 & 5,9 & 6,2 & 5,7 & 5,7 \\
\hline & & $\begin{array}{l}\text { Kete } \\
\mathrm{X} \\
\mathrm{S} \\
\mathrm{LKa} \\
\mathrm{LK} \mathrm{i} \\
\mathrm{R} \\
\mathrm{K}\end{array}$ & $\begin{array}{r}\text { anga } \\
= \\
= \\
=1 \\
=1 \\
=1 \\
=1\end{array}$ & $\begin{array}{l}\text { ata-r } \\
\text { mpa } \\
\text { enga } \\
\text { enga } \\
\text { elak } \\
\text { ontr }\end{array}$ & $\begin{array}{l}\operatorname{ta}(\mathrm{c} \\
\text { gan } \\
\text { Kan } \\
\text { Kiri } \\
\text { si }\end{array}$ & $\begin{array}{l}\mathrm{kku} \\
\mathrm{n}\end{array}$ & & & & & & & & & & \\
\hline
\end{tabular}

Tabel 2

Uji Normalitas Sistem Latihan Piramid Normal dan Terbalik pada Otot Lengan dan Paha

\begin{tabular}{|l|c|c|c|c|c|c|c|}
\hline \multirow{2}{*}{ Kelompok } & \multicolumn{3}{|c|}{ Kolmogorov-Smirnov ${ }^{a}$} & \multicolumn{3}{c|}{ Shapiro-Wilk } & \multirow{2}{*}{ Ket } \\
\cline { 2 - 7 } & Statistic & df & Sig. & Statistic & df & Sig. & \\
\hline Tes Awal L Ka R &, 167 & 10 &, $200^{*}$ &, 949 & 10 &, 654 & \multirow{2}{*}{ Normal } \\
\hline Tes Awal LKa K &, 126 & 10 &, $200^{*}$ &, 971 & 10 &, 904 & Normal \\
\hline Tes Awal LKi R &, 189 & 10 &, $200^{*}$ &, 920 & 10 &, 360 & Normal \\
\hline Tes Awal LKi K &, 151 & 10 &, $200^{*}$ &, 927 & 10 &, 417 & Normal \\
\hline Tes Akhir LKa R &, 166 & 10 &, $200^{*}$ &, 956 & 10 &, 744 & Normal \\
\hline Tes Akhir LKa K &, 135 & 10 &, $200^{*}$ &, 974 & 10 &, 924 & Normal \\
\hline Tes Akhir LKi R &, 174 & 10 &, $200^{*}$ &, 931 & 10 &, 462 & Normal \\
\hline Tes Akhir LKi K &, 157 & 10 &, $200^{*}$ &, 935 & 10 &, 504 & Normal \\
\hline
\end{tabular}

Berdasarkan hasil pengujian normalitas diatas, dapat dilihat bahwa semua data dinyatakan normal karena taraf signifikansi $>0,05$.

Tabel 3

Uji Homogenitas Sistem Latihan Piramid Normal dan Terbalik pada Otot Lengan dan Paha 


\begin{tabular}{|l|c|c|c|}
\hline \multicolumn{1}{|c|}{ Kelompok } & N & Correlation & Sig. \\
\hline $\begin{array}{l}\text { Tes Awal L Ka R \& } \\
\text { Tes Akhir L Ka R }\end{array}$ & 10 &, 996 &, 000 \\
\hline $\begin{array}{l}\text { Tes Awal L Ka K \& } \\
\text { Tes Akhir L Ka K }\end{array}$ & 10 &, 998 &, 000 \\
\hline $\begin{array}{l}\text { Tes Awal L Ki R \& } \\
\text { Tes Akhir L Ki R }\end{array}$ & 10 &, 998 &, 000 \\
\hline $\begin{array}{l}\text { Tes Awal L Ki K \& } \\
\text { Tes Akhir L Ki K }\end{array}$ & 10 &, 998 &, 000 \\
\hline
\end{tabular}

Dari hasil perhitungan pada tabel diatas hasil korelasi semua data menghasilkan angka 0,999 dengan nilai probabilitas atau nilai signifikansi 0,000 karena nilai probabilitas lebih besar $<$ dari nilai korelasi. Hal ini menyatakan bahwa korelasi antara tes awal dan tes akhir adalah sangat erat dan benar-benar berhubungan secara nyata.

\begin{tabular}{|l|c|c|c|c|c|l|}
\hline \multicolumn{1}{|c|}{ Kelompok } & Mean & $d f$ & T hitung & T tabel & $\begin{array}{c}\text { Sig. } \\
(2 \text {-tailed })\end{array}$ & Ket \\
\hline $\begin{array}{l}\text { Selisih SLPN L Ka R - } \\
\text { SLPT L Ka R }\end{array}$ & $0,2 \mathrm{~cm}$ & 9 & 2,553 & 1,833 &, 031 & Signifikan \\
\hline $\begin{array}{l}\text { Selisih SLPN L Ka K- } \\
\text { SLPT L Ka K }\end{array}$ & $0,2 \mathrm{~cm}$ & 9 & 2,973 & 1,833 &, 016 & Signifikan \\
\hline $\begin{array}{l}\text { Selisih SLPN L Ki R - } \\
\text { SLPT L Ki R }\end{array}$ & $0,2 \mathrm{~cm}$ & 9 & 2,553 & 1,833 &, 031 & Signifikan \\
\hline $\begin{array}{l}\text { Selisih SLPN L Ki K - } \\
\text { SLPT L Ki K }\end{array}$ & $0,2 \mathrm{~cm}$ & 9 & 3,273 & 1,833 &, 010 & Signifikan \\
\hline
\end{tabular}

Berdasarkan selisih pada lengan kanan dan kiri antara sistem latihan pramid normal dan terbalik $\mathrm{t}$ hitung $>\mathrm{t}$ tabel dan nilai probabilitas $<0,025$, maka Ho ditolak. Jadi, terdapat perbedaan yang signifikan antara metode latihan piramid normal dan terbalik terhadap peningkatan hipertrofi otot lengan. Dengan perbedaan Lengan Kanan saat Relaksasi, Lengan Kanan saat Kontraksi dan Lengan Kiri saat Relaksasi adalah 0,2 cm, Lengan Kiri saat Kontraksi adalah $0,2 \mathrm{~cm}$.

Kelompok metode latihan piramid normal dan terbalik pada bagian paha saat relaksasi $\mathrm{t}$ hitung adalah 2,739, saat kontraksi 4,302, dan $\mathrm{t}$ tabel 1,833 , dan nilai probabilitas $0,023 / 2=$ $0,0115,0,002 / 2=0,001$ karena $\mathrm{t}$ hitung $>\mathrm{t}$ tabel serta nilai probabilitas $<0,025$ maka $\mathrm{H}_{\mathrm{o}}$ ditolak dapat disimpulkan bahwa terdapat perbedaan yang signifikan antara metode latihan piramid normal dan terbalik terhadap peningkatan hipertrofi otot paha. Dengan perbedaan Paha Kanan saatRelaksasi 0,2 cm, Paha Kanan saat Kontraksi 0,3 cm dan Paha Kiri saat Relaksasi 0,2 cm, Paha Kiri saat Kontraksi 0,3 cm.

\section{Hasil dan Pembahasan}

Hasil pengamatan penulis selama satu bulan atau dua belas kali latihan dengan frekuensi tiga kali latihan selama satu minggu melakukan penelitian metode latihan piramid normal dan 
terbalik terhadap peningkatan hipertrofi otot lengan dan paha karena otot lengan dan paha lebih mudah dilakukan pengukurannya.

Dalam penelitian ini penulis menggunakan program latihan standing dumbell curl untuk melihat peningkatan hipertrofi otot lengan dengan pelaksanaan latihan sebagai berikut:

1. Memulai posisi berdiri dengan kaki selebar bahu,

2. Genggam sepasang dumbel dengan pegangan underhand grip,

3. Jaga agar sendi sikut dekat dengan pinggang atau area pinggul samping

4. Jaga bagian tubuh belakang tegak dan netral

5. Tekuk sendi sikut hingga batas maksimum range of motion

6. Luruskan sendi sikut ke posisi semula.

Sedangkan untuk melihat peningkatan hipertrofi otot paha digunakan latihan leg extension dengan pelaksanaan latihan sebagai berikut:

1. Memulai posisi duduk tegak lurus dengan kaki menggantung kebawah, bagian punggung kaki untuk mengatasi beban pada saat meluruskan dan membengkokan kaki

2. Kedua tangan lurus disamping memegang pegangan yang tersedia pada alat, beban diangkat dengan cara meluruskan kedua tungkai kedepan secara bersamaan dan berulang-ulang dengan meluruskan dan membengkokan lutut

Setelah melakukan penelitian, pengukuran atau tes awal dan tes akhir, serta perhitungan statistik pada bagian otot lengan yang menggunakan metode latihan piramid normal dan piramid terbalik terdapat pengaruh terhadap peningkatan hipertrofi ototnya. Hal ini menunjukkan, terdapat perbedaan yang signifikan antara metode latihan piramid normal dan piramid terbalik terhadap peningkatan hipertrofi ototlengan, dengan sistem latihan piramid normal yang menunjukkan peningkatannya lebih baik daripada sistem piramid terbalik. Dengan perbedaan $0,2 \mathrm{~cm}$.

Pada bagian otot paha yang menggunakan metode latihan piramid normal dan terbalik terdapat pengaruh terhadap peningkatan hipertrofi ototnya namun terdapat perbedaan yang signifikan antara metode latihan piramid normal dan piramid terbalik terhadap peningkatan hipertrofi otot paha, dengan sistem latihan piramid normal yang lebih menunjukkan peningkatanya daripada sistem latihan piramid terbalik. Dengan perbedaan Paha Kanan saat Relaksasi 0,2 cm, Paha Kanan saat Kontraksi 0,3 cm dan Paha Kiri saat Relaksasi 0,2 cm, Paha Kiri saat Kontraksi 0,3 cm.

Penelitian yang menggunakan metode latihan piramid normal memberikan pengaruh yang lebih signifikan terhadap peningkatan hipertrofi otot lengan dan paha karena latihan piramid normal ini diawali dengan beban yang ringan menuju beban yang berat sehingga akan 
menguntungkan otot dalam percepatan adaptasi dan otot-otot akan bekerja maksimal sehingga terdapat kemajuan dari sisi peningkatan menuju perubahan pada intensitas.

Metode latihan piramid terbalik juga memberikan pengaruh terhadap peningkatan hipertrofi otot lengan dan paha tetapi tidak sebanding pengaruhnya dengan metode latihan piramid normal, metode latihan pyramid terbalik ini membutuhkan adaptasi beban yang maksimal untuk mengawali latihan pembebanan karena otot-otot dituntut untuk memberikan kualitas kerja yang maksimal sehingga otot akan merasakan kelelahan untuk melakukan set berikutnya.

Dilihat dari selisih antara metode latihan piramid normal dan terbalik terhadap peningkatan hipertrofi otot lengan dan paha, yang lebih menunjukkan peningkatan yang lebih baik yaitu pada otot lengan pada saat relaksasi sedangkan pada saat kontraksi pada otot paha.

\section{Kesimpulan}

Kesimpulan dibuat berdasarkan hasil pengolahan dan analisis data tentang perbandingan metode latihan piramid normal dan piramid terbalik terhadap penigkatan hipertrofi otot. Maka dari itu penulis dapat mengambil beberapa kesimpulan dibawah ini:

1. Terdapat pengaruh dari metode latihan piramid normal terhadap peningkatan hipertrofi otot lengan dan otot paha

2. Terdapat pengaruh dari metode latihan piramid terbalik terhadap peningkatan hipertrofi otot lengan dan otot paha.

3. Metode latihan piramid normal memberikan pengaruh yang lebih baik terhadap peningkatan hipertrofi otot lengan dan otot paha dibandingkan dengan metode latihan piramid terbalik.

\section{Daftar Pustaka(11 pt)}

Dwyer, \& Davis. (2005). (ACSM) The American College of Sport and Medicine Health Related Physical Fitness Manual. Pennsylvania: Lippincott Williams \& Wilkins.

Harsono. (1988). Coaching dan Aspek-Aspek Psikologi dalam Coaching. Jakarta: CV. Tambak Kusuma. Imanudin, I. (2008). Ilmu Kepelatihan Olahraga. Bandung: Universitas Pendidikan Indonesia

Komarudin.(2007). Penerapan metode latihan beban dan latihan elastic tubing dalam meningkatkan prestasi memanah jarak 30 meter. Banda Aceh: Pusat Kajian Ilmu Olahraga Universitas Syiah Kuala.

Santosa, S. (2009). Panduan Lengkap Menguasai Statistika dengan SPSS 17. Jakarta: Kompas Gramedia.

Skripsi Sarjana Pada FPOK UPI Bandung: Tidak Diterbitkan.

http://muscle.ucsd.edu/musintro/hypertrophy.shtml

http://www.flexonline.com/2009_mr_olympia_final_results/news/958. 